\title{
A Critical Intervention for Urban Sociology
}

\author{
Elizabeth Korver-Glenn† \\ University of New Mexico \\ Prentiss Dantzler \\ University of Toronto \\ Junia Howell \\ University of Illinois at Chicago
}

\begin{abstract}
Cite as: Korver-Glenn, Elizabeth, Prentiss Dantzler, and Junia Howell. 2021. "A Critical Intervention for Urban Sociology." Invited chapter prepared for The Racial Structure of Sociological Thought (under review), edited by Victor Ray and Jennifer Mueller. https://osf.io/preprints/socarxiv/zrj7s/
\end{abstract}

Abstract: U.S. urban sociology continues to be dominated by the Chicago School's theories and methodological approaches. While yielding valuable insight regarding the importance of place, this body of work reproduces racism through explicit and implicit appeals to White-centered sensibility and desirability. In this chapter, we examine two specific Chicago School-inspired theories and related empirical work - spatial assimilation and place stratification. We draw from Du Boisian, racial capitalism, and other critical perspectives to illuminate the racial logics buoying this research. Where urban sociology underscores linear progression towards or digression from Whiteness, we emphasize urban heterogeneity and the intentional, non-linear or cyclical production of urban communities. Further, we argue that urban sociology must reckon with the racist roots of some of its most popular theories and methods, and recommend that future work explicitly center the mutually constitutive racism-capitalism-urbanization processes that have long shaped cities in the U.S. and around the world.

$\dagger$ Please direct correspondence to Elizabeth Korver-Glenn, Assistant Professor of Sociology, University of New Mexico, 1915 Roma NE Ste. 1103, MSC05 3080, Albuquerque, NM 87131; ekg@unm.edu 


\section{A Critical Intervention for Urban Sociology}

In 1892, the University of Chicago established the first formal department of Sociology. Here, a group of almost exclusively White men institutionalized U.S. sociology and, in particular, its urban arm. ${ }^{1}$ Often referred to as the 'Chicago School,' these early sociologists' theories and methods became the dominant sociological approach for a century (Itzigsohn and Brown 2020). Recognizing that the Chicago School's theoretical arguments did not fully capture urbanization processes unfolding across the world, some scholars questioned and altered these theories (e.g., Dear 2001; Logan 1978; Harvey 1978; Logan and Molotch 1987). Yet, the Chicago School's foundational assumption - that space is inherently hierarchical-remains prevalent throughout U.S. urban sociology. Built on explicit assertions of White superiority, this assumption continues to elevate Whiteness and marginalize communities of color.

As scholars who were trained in the Chicago School tradition, we have benefited from many urban sociological insights. Specifically, we are indebted to and appreciate how this legacy has highlighted the importance of communities in shaping residents' wellbeing. Nevertheless, we critique our subfield in an effort to build a more equitable approach to studying cities and urban areas. We argue that urban scholars must critically examine how our theories were shaped by and uphold racial hierarchies. In this chapter, we outline these critiques and propose a new theoretical and methodological approach that recognizes the central role race plays in urbanization, urban life, and neighborhood change.

\section{THE CHICAGO SCHOOL AND ITS RACIAL EPISTEMOLOGY}

Sociology and the social sciences more broadly began as a collection of scholars wrestling with the social implications of a rapidly industrializing and urbanizing world (Calhoun 2007). These scholars recognized that, for their theories and research to be taken seriously, they needed academic legitimacy. To achieve this legitimacy, White scholars from around the world convened at the 1904 International Congress of Arts and Science in St. Louis, Missouri to discuss and define the newly emerging social science fields (Morris 2015). Representatives from a wide variety of fields, including Albion Small - the department chair of the newly formed, first ever sociology department at the University of Chicago - attended the gathering. Yet, Black, Indigenous, and other scholars of color were noticeably absent from the Congress.

Despite their impeccable publishing records, sophisticated methodological innovations, and growing global notoriety, W.E.B. Du Bois, Ida B. Wells, and other emerging Asian, Black, Indigenous, and Latinx scholars - including Laura Cornelius Kellog, Shyamki Krishna Varma, and Salvador Brau — were not invited or allowed to participate in the St. Louis Congress (Go

\footnotetext{
${ }^{1}$ Throughout this chapter, we capitalize all racial categories (e.g. Asian, Black, Indigenous, Latinx, and White). Building off Du Bois's legacy and aligning with other contemporary scholars, such as Noel Cazenave and Wendy Roth, we argue capitalization draws attention to the fact that these are not mere descriptive adjectives but socially constructed categories. We recognize this has become an increasingly accepted practice when discussing Black people, but remains contentious when discussing White people. We respect those who deliberately lowercase white to decenter Whiteness and its destructive dominance. However, we argue capitalizing White highlights how it is a socially constructed cultural and political category that is no more "natural" or "given" than any other socially constructed racial grouping.
} 
2020). White sociologists and social scientists who excluded these individuals were also marginalizing an entire approach to the social sciences, fortifying its epistemic structural foundations. The White scholars conferring at the St. Louis conference contended society was shaped by universal, natural, and inevitable 'scientific' laws (Morris 2015). Conversely, Du Bois, Wells, and other marginalized scholars argued society was created by a collection of human actions and behaviors that could be identified through systematic observation (Bay 2009; Du Bois 2000; Itzigsohn and Brown 2020). By deliberately excluding and belittling insights from scholars of color, the White scholars at the St. Louis conference institutionalized sociology as a field that applied deterministic natural science theories to social phenomena and racist social practices to its own formation.

\section{Explaining Urbanization from a White Perspective}

Following the approach outlined at the St. Louis conference, Albion Small and his colleagues at the Chicago School borrowed from the natural sciences to derive theories of urban life. Specifically, Robert Park, Ernest Burgess, Louis Wirth, and Roderick McKenzie used Darwinism and ecology to create their concentric zone theory. They argued urbanization (the formation and development of urban communities) and urbanism (how cities influenced the lives of their residents) were both shaped by urban neighborhoods (Park and Burgess 1967; Zorbaugh 1929; see also Abbott 1997).

Using Darwin's theories of evolution, the Chicago School conceptualized these urban neighborhoods as spanning an evolutionary process from the least to the most 'civilized.' In particular, they argued these neighborhoods were structured in a series of hierarchical zoneswhere the least desirable places were closest to the urban core while the most desirable were the farthest away. Known as the concentric zone theory, Park, Burgess, and McKenzie argued that people with similar cultural and economic characteristics would find themselves living within the same zone (Park and Burgess 1967:54). ${ }^{2}$ They posited newer, 'unsophisticated' migrants initially settled in the least desirable neighborhoods closest to the urban core. Specifically, they stated: "In the zone of deterioration encircling the central business section are always to be found the socalled 'slums' and 'bad lands,' with their submerged regions of poverty, degradation, and disease, and their underworlds of crime and vice" (Park and Burgess 1967:54). To Park and Burgess, these neighborhoods were the nexus of problematic social ills. Yet, these communities were not the entirety of the city.

Moving out from the urban core were neighborhoods inhabited by "skilled and thrifty" factory and shop workers (Park and Burgess 1967:56). Park and Burgess posited these residents were second generation immigrants who had 'assimilated' and become upwardly economically mobile. Likewise, people of still higher socioeconomic statuses, who lived in "single family dwellings" and were the city's "best families," occupied the next, further-out zone (Park and Burgess 1967:50-51). These outer zones demonstrated the promise of the city and how the evolutionary process created idealized 'modern' communities.

\footnotetext{
${ }^{2}$ Note that Roderick McKenzie composed chapter three of Park and Burgess's volume, from which some of the quotes in this chapter were taken. McKenzie's explicit statements exemplify Park and Burgess's overall approach.
} 
Park and Burgess argued residents move through these zones as they experienced upward mobility. When residents moved into new communities, those currently living in the more "desirable" communities also moved "up" to even "better" neighborhoods as they accumulated more wealth and status. But they largely ignored how such mobility occurred. Instead, they assumed that residents achieved residential mobility through a 'natural' process rather than through intentional urban planning or intervention. Although loosely inspired by Chicago's neighborhoods, Park, Burgess, and McKenzie acknowledged no city, not even Chicago, "perfectly" fit their theory (Park and Burgess 1967:52). Instead, they explained that their theory was based on Darwinism and ecology. Using established theories in the natural sciences instead of closely examining and reflecting on observed urban reality served to increase their academic legitimacy (Du Bois 2000; Itzigsohn and Brown 2020; Morris 2015). At the same time, it required assumptions about White superiority to justify inconsistencies between their theory and observed patterns of neighborhood change.

\section{Othering Blackness, Mis-theorizing Cities}

Alongside naturalizing White (neighborhood) superiority, the Chicago School cast Black communities as the 'exception' to their urban theory 'rule.' For instance, Park, Burgess, and McKenzie (1967) claimed Black city-dwellers were a noteworthy exception to their theory in their seminal monograph. However, rather than recognizing this exception as a shortcoming in their theory, they argued it was evidence of Black urbanites' perceived biological 'inferiority.' Building on White supremacist ideologies, they asserted Black residents' perceived 'inferiority' meant they could not be 'emancipated' by the city's economic prowess or assimilated into its more desirable zones (Morris 2015). Instead, Black city-dwellers were perpetually akin to recently arrived "immigrants from Europe" (Park and Burgess 1967:108). Park and Burgess (1967:108) reasoned that this supposed inability to adapt to the "foreign" environment explained "the enormous amount of delinquency, juvenile and adult, that exists today in Negro communities in northern cities."

If Park, Burgess, and McKenzie had taken an empirical approach, they would have recognized that the Black experience was illumining the urbanization processes for everyone. That is, the Black experience demonstrated that urbanization was not an evolutionary, deterministic process. Instead, policies and organizational practices shaped who was able to live where and to what extent they had access to the resources within the city. The Chicago School could have used their empirical evidence to challenge and refine theory to incorporate the role of social policy in urbanization. However, they chose instead to follow the precedent laid out at the St. Louis Congress: they used natural science theories to explain social phenomena and the exceptions to these phenomena. In particular, they pulled on social Darwinism and prevalent assertions of White superiority to dismiss the importance of Black communities' stories all together. In doing so, they reinforced the idea and practice of 'understanding' urban phenomena with generalizable theories, rather than from empirical observations of socially constructed and dynamic phenomena. Many urban sociologists went on to adopt the Chicago School's theoretical concepts and their methodological approach for most of the $20^{\text {th }}$ century.

THE CHICAGO SCHOOL'S ONGOING LEGACY: SPATIAL ASSIMILATION AND PLACE STRATIFICATION 
In the first half of the $20^{\text {th }}$ century, urban sociologists conducted ethnographies that framed Black communities as 'disordered' and inferior to White neighborhoods (e.g., Wirth 1928). Simultaneously, quantitative urban scholars operationalized residential segregation and 'attainment' such that White communities were evaluated as superior (e.g., Duncan and Duncan 1955). These approaches hid their theoretical reliance on White supremacy and thus presented their 'findings' as objective empirical justifications for racist, false beliefs about Black inferiority.

In the latter half of the $20^{\text {th }}$ century, White scholars began to admit that the ideology used to justify the concentric zone theory was overtly racist. Consequently, urban sociologists replaced the racist explanation of Black 'exceptionalism' with the ostensibly more progressive explanation that Black people experienced high levels of racial discrimination and were thus unable to conform to the general model of social-spatial mobility (e.g., Drake and Cayton 1945; Duncan and Duncan 1957; Duneier 2016; Jackson 1985; Johnson 1943). However, the tenets of the theory-method remained unquestioned. In doing so, scholars were able to adjust for the evolving racial ideology while preserving the idea that the city is a collection of defined, monolithic neighborhoods that are hierarchical in nature (Duneier 2016; Irby 2015; Madden 2014).

Specifically, the Chicago School's ideas were refashioned into two prominent, contemporary urban sociological theories: spatial assimilation, or locational attainment, and place stratification. Both of these theories build directly on the ecological (i.e., spatial-social) legacy of the Chicago School by calling attention to the importance of space and place in shaping cities and their residents (Logan and Molotch 1987; Sampson 2012).

\section{Spatial Assimilation Theory and Its Racialized Assumptions}

Spatial assimilation theorists argue that as socially marginalized residents-including immigrants and people of color - accumulate human, economic, and social capital, they will convert their capital into spatial mobility, moving into Whiter and higher-income areas (Alba and Logan 1993; Iceland and Wilkes 2006; Massey and Denton 1985; Rugh 2015). Like the original Chicago School theory, spatial assimilation theorists conceptualize neighborhoods as homogenous; view White and/or high-income neighborhoods as the preferred standard by which upward and outward spatial and social mobility are determined; and understand such mobility as a linear progress (Rugh 2015). That is, they use Whiteness as the standard by which Asian, Black, and Latinx social 'progress' should be understood. ${ }^{3}$ Methodologically, they operationalize this progress through statistical models that measure the extent to which immigrants or people of color move into White and/or higher socioeconomic status neighborhoods. Much like the early studies conducted by the Chicago School, these models assume residents' socioeconomic status (e.g., education, income) shapes urbanization trajectories and neighborhood locations - not their race or experiences of racism.

\footnotetext{
${ }^{3}$ Like sociological research more broadly (e.g. Norgaard 2019; McKay, Vinyeta, and Norgaard 2020), urban sociologists who use these theories typically leave out or ignore urban Indigenous populations.
} 
The following quote concisely illustrates contemporary understandings and uses of spatial assimilation theory. Iceland and Wilkes (2006:250) state that:

According to the spatial assimilation theory, these [systematic] SES differences [across racial groups], by themselves, should result in some racial and ethnic segregation, even if there were no prejudice and discrimination affecting people's residential choices. Those who achieve socioeconomic gains, however, can then translate them into higher quality neighborhoods and housing. This is noteworthy since residential mobility is a step toward more complete assimilation across other dimensions, such as social and political.... Richard Alba and John Logan (1991) note that: 'This process implies, on the one hand, a tendency toward dispersion of minority-group members, which opens the way for increased contact with members of the ethnic majority... and, on the other, greater resemblance in residential characteristics between successful minority-group members and their peers from the majority' (p. 443).

Iceland and Wilkes's (2006) summary of spatial assimilation provides a concrete example of how contemporary urban scholars understand and implement the theory. In doing so, they also illuminate its problematic racialized assumptions. First, spatial assimilation theorists assume that people of like socioeconomic status live with each other - that is, it assumes neighborhood socioeconomic homogeneity ("SES differences, by themselves, should result in some racial and ethnic segregation"). Second, spatial assimilation theorists also assume that homogenous White neighborhoods (with Whites as the 'ethnic majority') are "higher quality." Third, spatial assimilation theorists assume that moving into otherwise homogenous White neighborhoods will open up political and social opportunities for immigrants and people of color - that is, they will experience social progress. These assumptions continue to rely on the tenets of social Darwinism that presume the superiority of White and middle-class communities.

\section{Place Stratification Theory and Its White Foundations}

In contrast to spatial assimilation theory, place stratification theorists emphasize that socially marginalized people, including immigrants and people of color, are unable to convert their accumulated human, economic, and social capital into social and spatial mobility. This theory argues racial discrimination in the labor and housing markets traps immigrants and people of color in low-status neighborhoods (Logan 1978; Logan and Molotch 1987). Unlike the original Chicago School theory, place stratification theorists emphasize that urban neighborhoods are not 'natural areas' but rather are active creations of capitalist intervention and societal racism. However, place stratification theory still conceptualizes neighborhoods as hierarchical. Communities of color and low-income neighborhoods are deemed undesirable, especially in contrast to their White and upper-income counterparts. In this way, place stratification theory also relies on the Chicago School's White foundations.

For instance, Waren (2013:634) explains:

Alba and Logan (1991) use the phrase place stratification to describe the condition when African Americans are unable to convert their individual-level characteristics (e.g. education) into neighbourhood-level outcomes (e.g. neighbourhoods with a higher 
percent of white residents). This condition exists, for example, when high status blacks are unable to move to whiter neighbourhoods. Subsequently, this form of place stratification was relabeled as the 'strong' version of place stratification - where spatial position does not change regardless of changes in minority group status. That version is contrasted with a 'weak' version of place stratification, wherein African Americans can convert their individual-level characteristics into more desired neighbourhood-level outcomes, but at much lower rates than other groups.... [emphases original]

Like spatial assimilation theorists, place stratification theorists assume neighborhood homogeneity through reference to neighborhood status and location in the urban-spatial hierarchy. Moreover, even though the theory itself attributes problems in Black and Latinx neighborhoods to broader political-economic forces and discrimination, theorists who use it nonetheless apply a deficit-based lens to these neighborhoods by emphasizing concentrated poverty, crime, 'at-risk' youth, informality, and other deviations constructed in opposition to a 'pure' White mainstream. Place stratification theorists also assume that immigrants and people of color want to move to Whiter neighborhoods and will attempt to do so because of the presumed 'desirability' of resources and amenities concentrated in these areas. Unlike spatial assimilation theorists, place stratification theorists emphasize how immigrants and people of color are locked out of White neighborhoods, such that their options for acting on their desires are diminished or foreclosed (see also Rugh 2015). However, adopting this view requires taking the "desirability" of homogenous, White communities for granted, and assuming Black and Latinx people prefer White communities over their own. In other words, like spatial assimilation theorists, place stratification theorists presume the superiority of White and middle-class communities. Moreover, they rationalize people of color's residential mobility as an anomaly due to the racism they face instead of reckoning with what their experiences might say about urbanization more generally.

\section{UPROOTING THE RACISM WITHIN CONTEMPORARY URBAN SOCIOLOGY}

Tracing the connections between contemporary theories and the Chicago School illuminates how racist theoretical assumptions have continued to prevail in urban sociology. Yet even studies that do not explicitly use the Chicago School-inspired spatial assimilation or place stratification theories often still perpetuate the same racist assumptions. Fully uprooting the racist assumptions within the subfield requires identifying their prevalence throughout contemporary urban sociology. In particular, we argue the majority of contemporary urban sociology's theoretical and methodological foundations perpetuate two racialized assumptions: (1) White space is preferable and (2) race and class are distinct factors, neatly teased away from one another. Both of these assumptions are rooted in the Chicago School and continue to have consequences for urban sociological scholarship as well as the policy interventions such scholarship inspires.

\section{Assumption One: White Space Is Inherently Superior}

Across methodological approaches, topics (e.g., crime, housing, education, health, environment), and theoretical persuasions, urban sociologists continue to explicitly and implicitly presume White communities are the rubric by which all other communities should be evaluated. In fact, contemporary scholars often use moralistic language when discussing neighborhoods. It is not 
uncommon for urban sociologists to refer to White affluent communities as "good" or "better neighborhoods" and communities of color as "worse," "undesirable," and even "bad" (Howell 2019). This moralistic and naturalizing thinking is then reflected in methodological decisions. For instance, urban ethnographies routinely reference White neighborhoods as their implicit reference category while quantitative studies create indexes that presume Whiteness is the norm (Howell 2019). In making these methodological choices, urban sociologists both reify and hide Whiteness - it becomes the benchmark for measuring the value of every person and place, but in remaining unarticulated and undisclosed, it is (almost) undiscoverable and seemingly innocuous.

By assuming White space is superior, urban sociologists reproduce and reify the century-old practice of socially and economically evaluating White communities as worth more (see Howell and Korver-Glenn 2018, forthcoming; Korver-Glenn 2021; Taylor 2019) and minimizing the agency of immigrants and people of color to create and shape desirable communities in their own image (Connolly 2014). This has had direct implications on the policies these scholars promote and how their research is used to further justify urban initiatives that value Whiteness and White communities to the detriment of communities of color.

In recent decades, this has included researchers affirming the idea that neighborhoods are locations of either opportunity or despair. When translated into policy recommendations, this binary conception of communities reifies the presumed deficits of neighborhoods of color and further marginalizes community voices. Instead of allowing local residents to determine their own contextual forms of neighborhood satisfaction (Ciorici and Dantzler 2019; Jones and Dantzler 2020), urban sociologists use (hidden, White) socioeconomic outcome standards as their basis for development regardless of local residents' opinions or concerns.

\section{Assumption Two: Race and Class Are Distinct, Separable Factors}

In addition to assuming the superiority of White space, urban scholars also presume race and class can (and should) be distinguished as distinct factors shaping outcomes. Often this entails pitting race and class against each other to investigate which is more important in shaping outcomes: does class or race matter more? No matter how scholars answer this question, by asking it they ignore how cities and their residents have been shaped by and continually shape the mutually constitutive pillars of racism and economic exploitation (see, for example, Connolly 2014; Du Bois [1996]1899, [2014]1935; Robinson 2000; Zuberi and Bonilla-Silva 2008).

Methodologically, urban scholars operationalize this false divide between race and class by treating race and class as competing variables that explain distinct factors (Zuberi 2000; Zuberi and Bonilla-Silva 2008). This methodological approach legitimizes the narrative that these factors can be disentangled without wrestling with the reality of their mutual constitution. Moreover, these studies often do not contextualize how social and political factors shape the intersectional relationship between race and class. Instead, mirroring the Chicago School, scholars often implicitly treat one point of time as representative of broader patterns in urbanization and mobility (e.g., Jargowsky 1997; Massey and Eggers 1990; Quillian 2012). This ahistorical approach undermines the evolving and dynamic relationship between race and class. 
Theoretically, urban scholars tend to give explanatory primacy to race or class when examining contemporary urban processes, including in domains such as criminal justice, education, and housing. One illustration of race-or-class urban theory is the 'dual housing market' construct. This construct signifies that there are two separate and unequal markets that funnel housing consumers by race: Whites have access to one market and set of White neighborhoods, while individuals of color have access to a separate, inferior market that funnels them into communities of color through overt or covert practices (e.g., Apgar and Calder 2005; Rugh et al. 2015). Yet in emphasizing race over class, the 'dual housing market' concept misses how the housing market draws all of its participants into the same system that relies on and constructs hierarchical racialeconomic value. Housing market actors and industries devalue Black and Latinx mortgages, homes, and neighborhoods so that White mortgages, homes, and neighborhoods can be hypervalued; they hyper-value White mortgages, homes, and neighborhoods because Black and Latinx homes and neighborhoods are devalued (Connolly 2014; Howell and Korver Glenn 2018, forthcoming; Rugh et al. 2015; Taylor 2019). White housing gains precisely because Black and Brown housing loses. The involvement of Black and Brown people within the housing market masks the reality of a racialized political economy through several modalities of subjugation and racialized economic exploitation (see Taylor (2019) or Dantzler and Reynolds (2020)). By ignoring the structural dynamics of a unified housing market, urban sociologists' research ignores the larger exploitative and predatory practices within the market (Taylor 2019). As such, racial-economic disparities are not the separable byproducts but the entwined preconditions of urbanization, which facilitate the (re)production of urban inequality.

In addition, focusing purely on race and class between groups largely ignores heterogeneity within each group. For this reason, studies within urban scholarship tend to reproduce a narrative of White wealth and Black poverty, masking the socioeconomic diversity of all racial groups. By contrast, understanding the mutually constitutive race-and-class dynamics between and within groups prompts scholars to examine other questions, such as the degree to which communities work together, whether intentionally or unintentionally, to preserve their statuses (see Barnett 1993; Jackson 2001; Tach 2014). Instead of theorizing and measuring race and class as degrees of difference, work that prioritizes heterogeneity between and within groups would theorize and measure race and class as processes across a wide spectrum of outcomes.

\section{TOWARD A CRITICAL PERSPECTIVE ON URBAN SOCIOLOGY}

Recognizing how racism influenced the foundational theories and methods in urban sociology is a critical step towards building a more robust subfield. Yet, we argue that fully uprooting the racist and White supremacist assumptions within urban sociology requires us to allow empirical evidence to shape our theoretical predilections and propositions. As we outlined above, the Chicago School and their contemporaries attempted to gain legitimacy by borrowing theories from the natural sciences to explain the social world. Ironically, however, they failed to adapt the scientific principle that theories must be revised or discarded when they cannot be substantiated empirically (e.g., Lieberson 1991). Instead, they recused their White logics and methods by portraying all conflicting evidence as the result of Black urbanites' presumed anomalies (see also Ladner 1971). 
We argue that when the historical and contemporary evidence is fully taken into consideration, it is evident that race-conscious theories and methods provide a far more robust account of urbanization and urban life. Specifically, we propose building on the legacy of the habitually marginalized urban sociological work of Du Bois and the Atlanta School(Itzigsohn and Brown 2020; Morris 2015; Wright II 2006). The Atlanta School, which was established by Du Bois during his tenure at Atlanta University (1895-1924), had a program that revolved around understanding Black urbanity in the heart of a Black city at a historically Black college, regarded as one of the best schools in the South. Through systematic social scientific training, Du Bois, among others, trained many scholars to unpack and explore the social ills affecting Black city dwellers. Over the years, the Atlanta School provided research that benefited the city across many domains, including housing, employment, health, crime, and education. Many notable graduates would go on to work and build in this tradition, including Monroe Nathan Work, the first African American to have an article published in the American Journal of Sociology, and Lucy Craft Laney, the founder of the Haines Institute in Augusta, GA, who became a nationally recognized leader in secondary education (Wright 2009). While the Atlanta School (like Du Bois) never received the attention it deserved from White social scientists, its legacy and contributions to sociology more generally and urban sociology specifically have been enormous (see also Wright 2009). Building on these contributions and those of scholars who have worked in the spirit of the Atlanta School tradition-primarily Asian, Black, Indigenous, and Latinx sociologists - we propose two interventions for urban sociology to move beyond its exclusionary modes of thought and practice.

\section{Intervention 1: White Space Is Not Superior}

Intervention 1 is to adopt, in theory and method, the assumption that White space is not superior. There are three ways we see this working out practically in urban sociological research. First, we recommend abandoning the idea that urban neighborhoods are racially, socioeconomically, or otherwise homogenous and that White, high-socioeconomic status, homogenous neighborhoods are the most desirable areas. Building on work by Joyce A. Ladner (1971; 1988), Mary Pattillo (1999; 2007), Mario Small (2004; 2008; and with colleagues in 2018), Marcus Hunter and Zandria Robinson (2016; 2018), Robert Vargas (2016), and others, we argue that urban sociological theories and methods should excavate heterogeneity within and across neighborhoods. For example, Mario Small and colleagues (2018) examined changes in depopulation in poor communities between 1970-2010 for America's 100 largest cities. They found that while depopulation in poor neighborhoods was common in the 1990s, cities increasingly diverged in whether and to what extent poor neighborhoods became increasingly (de)populated across 2000 and 2010. In other words, by 2010, poor, depopulated urban neighborhoods were no longer the norm. Building on Small et al.'s (2018) work, we argue that urban sociology should take heterogeneity as its starting point in examining patterns of city growth and change. From adapting or discarding existing theories, to operationalizing variables and selecting models, to choosing field sites and populations, much work remains to be done to capture the complexities of urban life.

Moreover, such work should examine how and under what conditions urban gatekeepers such as housing developers and real estate agents appeal to heterogeneity and homogeneity to symbolically and physically construct urban space (Besbris and Korver-Glenn 2019; Korver- 
Glenn 2021). For instance, urban housing developers tend to assume that homogenous, White neighborhoods or neighborhoods that are increasingly White will bring in the most profit. In the case of the latter, they may highlight the area's 'diversity' to market it to a White audience while also marketing their homes as making the neighborhood more 'desirable' (Korver-Glenn 2021). In this instance, urban gatekeepers use heterogeneity as a marketing tool that is ultimately subsumed under the broader project of making urban space more homogenous and White. Such work would build on research describing population heterogeneity and explore how actors use (perceptions of) diversity or similarity to shape population heterogeneity or homogeneity.

Second, we propose abandoning a deficit-based approach to studying neighborhoods of color and adopting an asset-based approach instead. Echoing calls from others, including Dávila (2004), Hunter and Robinson (2016; 2018), Ray (2018; with Tillman 2019), Vargas (2016), Ladner (1971), and Rios (2011), we emphasize the creative power, agency, and social, cultural, symbolic, and economic capital inherent in communities of color rather than framing communities of color as dangerous, less desirable than White communities, or somehow deficient. Moreover, we emphasize that it is possible to assume an asset-based understanding of communities of color and call attention to the ways White actors and institutions have exploited and abandoned these communities. For example, Hunter and Robinson (2018) draw on the Black intellectual tradition of situating place as critically important to understanding "the linked destinies of Black communities and the consequences of enduring patterns of disadvantage and inequality while surviving and thriving as Black in the United States..." (p. xiii). Their approach mirrors much of the canonical writings of Du Bois' ([1996]1899) The Philadelphia Negro and Ida B. Wells' (1892-1894) Southern Horrors (see also Hunter and Robinson 2016).

Third, we urge urban sociologists not to assume a linear, progress-oriented model of urban growth and change (whether such growth is outwards in suburbanization or inward in gentrification processes). Instead, we propose an iterative, regressive lens to understanding urban growth and change. Specifically, rather than examining decision-making through a racial progress narrative of urban change (which equates proximity to Whiteness with progress (Seamster and Ray 2019)), we argue that urban growth and change often continues to be a product of White-controlled, iterative decision-making. We view such White-controlled, iterative decision-making as regressing towards the mean, or the status quo of White domination in all its urban forms. These forms include but are not limited to White-oriented housing markets, White racial segregation, and presumed White neighborhood desirability and value, among others. When urban residents of color resist White decisions, the repetitive, regressive nature of those decisions is made plain. They are also made plain when urban residents of color engage in their own creative place-making (Hunter et al 2016). Using this lens would mean that Black urban life and experiences and those of other people of color would no longer be an 'exception' to some abstract and many-times falsified 'rule.' Instead, their lives and experiences would be central to understanding urban spaces not just as sites of ongoing White supremacy in and across urban spaces, but as spaces of endurance, belonging, and resistance (Hunter et al. 2016).

\section{Intervention 2: Race and Class Are Mutually Constitutive}

Intervention 2 is to recognize, in theory and method as well as policy recommendations, that race and class are mutually constitutive. That is, these categories - and how they are pulled on, 
reproduced, or transformed in urban contexts - should be understood as dependent on (urban) systems of racial and economic exploitation. We propose two ways for urban sociologists to reckon with race-and-class (instead of race or class) in future research. First, we encourage a racial capitalism approach to understanding urban processes. Rather than viewing racial segregation, urban racial inequality, and other related phenomena as epiphenomenal to (the rise of) capitalism, urbanization, and industrialization as most urban theorists have, we advocate for a Du Boisian vision of cities that recognizes capitalism, racism, urbanization, and industrialization as inextricable (Connolly 2014; Du Bois [1996]1899, [2014]1935; Loughran 2015; Robinson 2000; Rucks-Ahidiana forthcoming). Under a racial capitalist-approach to studying cities, the question is not whether race or class matters more. Rather, a racial capitalist approach takes as its starting point the racialized-economic systems underpinning cities and seeks to understand how racism and economic exploitation are entwined, and to what effects. This approach begs us to unpack questions and phenomena that reckon with the modes and forms of production that tie social hierarchies to processes of legitimizing subjectivity within the (re)creation of urban spaces (Dantzler and Reynolds 2020).

Second, we urge urban sociologists to conceptualize race-and-class as processual and relational. Race and class are dynamic phenomena; so, too, is their relation to one another and the broader racial-capitalist system. With respect to the 'dual housing market' illustration above, for example, a processual and relational understanding of race-and-class might instead entail understanding housing markets as unified. There are not two separate and unequal markets that funnel people of color into areas of color and Whites into White areas. Instead, there is a single market in which White home and neighborhood hyper-value is predicated on the devaluing of individuals and neighborhoods of color within that same market (Connolly 2014). Whiteness exists only in relationship to an opposite object and, when it comes to cities and neighborhoods, Whites construct these opposite objects through appeals to supposed inherent differences in space and place and the people who inhabit space and place. In other words, if one side of the 'dual housing market' were to disappear, so too would the other side-suggesting these are not separate markets but rather one and the same. Other areas of study, including gentrification, residential and occupational segregation, placemaking, and development, could likewise benefit from a similar processual and relational approach.

\section{CONCLUSION}

The word "intervention" implies a health-related discussion of interruption for the sake of improving one's course of life. In this chapter, we have sought a similar path of intervening into the troubled nature of urban sociology in order to grapple and break with its racist roots. From its earlier considerations as a distinct subfield of scientific inquiry to its formation as a racial epistemology, urban sociologists must reckon with their role in reproducing racial hierarchy.

While we pay particular attention to spatial assimilation and place stratification as symptoms of the problem in this chapter, other areas of concern to urban sociologists could benefit from a similar critical analysis. For instance, segregation, gentrification, and eviction are deeply implicated in historical and contemporary race-and-class subjugation in the United States, yet only rarely do urban sociologists conceptualize and study these issues as part and parcel of racial and economic exploitation (and it is usually scholars of color who do so). Urban sociologists 
who study urban Black and Brown crime and poverty as well as neighborhood inequality tend to portray Black and Brown people and communities as problems to be solved. Such work hides or ignores structural racism as a root cause of poverty, crime, and hyper-policing. It also ignores or downplays research showing that communities of color routinely describe feeling satisfied with their neighborhoods (Ciorici and Dantzler 2019) and that residents of these neighborhoods cultivate creative solutions to structural exclusion (e.g., from labor markets or educational opportunities) (Ladner 1971). Policy recommendations coming from this research can reproduce racism in the public sphere, and can have real and negative consequences for communities of color. Universal policy recommendations relying on the class position of White communities have the tendency to evaluate Black and Brown communities on their proximity towards Whiteness. Given the inherent racialized history of urban spaces, we advocate for policy recommendations that consider the particular contextual factors (re)shaping communities. This approach supports collective efforts that allow communities to articulate their own desires while maintaining forms of placemaking to address urban inequalities (Hunter et al. 2016).

To break with urban sociology's racist roots and the inequitable policy recommendations that have emerged from this legacy, we advocate that urban sociologists interrogate the assumptions undergirding their research questions and methodological choices. One way to do so is to use the two interventions outlined above as a springboard to question one's own and others' theoretical and methodological decisions. And, then, to arrive at answers and recommendations that reject homogeneity, Whiteness, false dichotomies, and intellectually dishonest optimism as the (unspoken) standards for urban sociological research. How do presumptions about homogeneity and desirability shape the conceptualization of the research question? Which group is the reference group, and why? What are the structural sources of crime? Should we discuss "race effects" or racism's effects? How do residents themselves feel about their neighborhoods? What creative solutions have residents of Black and Brown communities already adopted to navigate racism and other forms of structural exclusion? In what ways are actors seeking to preserve or disrupt the status quo? Are race and class ever operating 'independently'? What is the relationship between White neighborhoods and neighborhoods of color? And how do our policy recommendations disrupt or reinforce notions of Whiteness as the objective?

Emerging from the scholars that have long been marginalized but never fully silenced in urban sociology, these and other questions and critical answers can become antidotes for the subfield. To become healthy - to abandon its racist roots and pursue a research program that equitably values communities of color - urban sociology must take its medicine.

\section{REFERENCES}

Abbott, Andrew. 1997. "Of Time and Space: The Continuing Relevance of the Chicago School." Social Forces 75(4):1149-82.

Alba, Richard D. and John R. Logan. 1993. "Minority Proximity to Whites in Suburbs: An Individual-Level Analysis of Segregation." American Journal of Sociology 1388-1427.

Apgar, William C. and Allegra Calder. 2005. "The Dual Mortgage Market: The Persistence of Discrimination in Mortgage Lending." Pp. 101-24 in The Geography of Opportunity: 
Race and Housing Choice in Metropolitan America, edited by Xavier Souza de Briggs. Washington, D.C.: Brookings Institution Press.

Barnett, B. M. (1993). Invisible southern black women leaders in the civil rights movement: The triple constraints of gender, race, and class. Gender \& Society, 7(2), 162-182.

Bay, Mia. 2009. To Tell the Truth Freely: The Life of Ida B. Wells. New York: Hill and Wang.

Besbris, Max and Elizabeth Korver-Glenn. 2019. "Houses Are Everything: Toward a Theory of Valuation in the Housing Market." Paper presented at the Institute for Analytical Sociology, Norrköping University, September 9, 2019.

Calhoun, Craig (ed). 2007. Sociology in America: A History. Chicago, IL: University of Chicago Press.

Ciorici, Patricia, and Prentiss A. Dantzler. 2019. "Neighborhood Satisfaction: A Study of a LowIncome Urban Community." Urban Affairs Review 55(6): 1702-1730.

Connolly, N. D. B. 2014. A World More Concrete: Real Estate and the Remaking of Jim Crow South Florida. University of Chicago Press.

Dantzler, Prentiss A. and Aja D. Reynolds. 2020. "Making Our Way Home: Housing Policy, Racial Capitalism, and Reparations." Journal of World-Systems Research 26(2): 155-167.

Dear, Michael. 2001. From Chicago to LA: Making Sense of Urban Theory. Thousand Oaks, CA: Sage Publications.

Drake, St Clair and Horace R. Cayton. 2015. Black Metropolis: A Study of Negro Life in a Northern City. University of Chicago Press.

Du Bois, W.E.B. ([1996]1899). The Philadelphia Negro: A social study. Philadelphia, PA: University of Pennsylvania Press.

Du Bois, W.E.B. 2000. "Sociology Hesitant.” Boundary 2 27(3):37-44.

Du Bois, W.E.B. [2014]1935. Black Reconstruction in America : An Essay Toward A History Of The Part Which Black Folk Played In The Attempt To Reconstruct Democracy In America, 1860-1880. New York, NY: Oxford University Press,

Duncan, Otis Dudley and Beverly Duncan. 1955. "A methodological analysis of segregation indexes." American Sociological Review 20: 210-17.

Duncan, Otis Dudley and Beverly Duncan. 1957. The Negro Population of Chicago: A Study of Residential Succession. Chicago, IL: University of Chicago Press.

Duneier, Mitchell. 2016. Ghetto: The Invention of a Place, the History of an Idea. New York, NY: Farrar, Straus and Giroux.

Durkheim, Emile. 2001 (1912). The Elementary Forms of Religious Life. (Carol Cosman, Trans.). Oxford: Oxford University Press.

Go, Julian. 2020. "Race, Empire, and Epistemic Exclusion: or the Structures of Sociological Thought." Sociological Theory DOI: 0735275120926213.

Gonzalez Van Cleve, Nicole. 2016. Crook County: Racism and Injustice in America's Largest Criminal Court. Stanford University Press.

Harris, Cheryl I. 1993. "Whiteness as Property." Harvard Law Review 106(8):1707-1791.

Harvey, David. 1978. "The Urban Process under Capitalism: A Framework for Analysis.” International Journal of Urban and Regional Research 2(1-3):101-31.

Howell, Junia. 2019. "The Unstudied Reference Neighborhood: Towards a Critical Theory of Empirical Neighborhood Studies.” Sociology Compass 13(1):e12649.

Howell, Junia and Elizabeth Korver-Glenn. 2018. "Neighborhoods, Race, and the Twenty-FirstCentury Housing Appraisal Industry." Sociology of Race and Ethnicity 4(4):473-90. 
Howell, Junia and Elizabeth Korver-Glenn. 2019. "The Increasing Effect of Neighborhood Racial Composition on Housing Values across the U.S., 1990-2010.” Paper presented at the American Sociological Association Annual Conference, Regular Session. New York, NY. August 10-13, 2019.

Hunter, Marcus, Mary Pattillo, Zandria F. Robinson, and Keeanga-Yamahtta Taylor. 2016. "Black Placemaking: Celebration, Play, and Poetry" Theory, Culture \& Society 33(7-8): 31-56.

Hunter, Marcus and Zandria Robinson. 2018. Chocolate Cities: The Black Map of American Life. Oakland: University of California Press.

Hunter, Marcus and Zandria Robinson. 2016. "The Sociology of Urban Black America." Annual Review of Sociology 42(1): 385-405.

Iceland, John and Rima Wilkes. 2006. "Does Socioeconomic Status Matter? Race, Class, and Residential Segregation." Social Problems 53(2):248-73.

Irby, Decoteau. J. 2015. "Urban is Floating Face Down In The Mainstream: Using Hip-HopBased Education Research To Resurrect “The Urban” In Urban Education.” Urban Education, 50(1):7-30.

Itzigsohn, Jose and Karida L. Brown. 2020. The Sociology of W. E. B. Du Bois: Racialized Modernity and the Global Color Line. New York, NY: New York University Press.

Jackson, J. L. (2001). Harlemworld: Doing race and class in contemporary Black America. University of Chicago Press.

Jackson, Kenneth T. 1987. Crabgrass Frontier: The Suburbanization of the United States. Oxford University Press.

Jargowsky, Paul. 1997. Poverty and Place: Ghettos, Barrios, and the American City. New York, NY: Russell Sage.

Johnson, Charles S. 1943. Patterns of Negro Segregation. New York, NY: Harper and Brothers.

Jones, Antwan and Prentiss A. Dantzler. 2020. "Neighbourhood Perceptions and Residential Mobility." Urban Studies DOI: 0042098020916440.

Korver-Glenn, Elizabeth. Forthcoming. Race Brokers: Housing Markets and Durable Segregation in $21^{\text {st }}$ Century Urban America. Oxford University Press.

Ladner, Joyce A. 1971. Tomorrow's Tomorrow. Lincoln, NE: University of Nebraska Press.

Ladner, Joyce A. 1988. The Death of White Sociology. Baltimore, MD: Black Classic Press.

Logan, John R. 1978. "Growth, Politics, and the Stratification of Places." American Journal of Sociology 84(2):404-16.

Logan, John R. and Harvey Luskin Molotch. 1987. Urban Fortunes: The Political Economy of Place. University of California Press.

Loughran, Kevin. 2015. "The Philadelphia Negro and the Canon of Classical Urban Theory." Du Bois Review: Social Science Research on Race 12(2):249-67.

Madden, David J. 2014. "Neighborhood as Spatial Project: Making The Urban Order On The Downtown Brooklyn Waterfront." International Journal of Urban and Regional Research. 38(2):471-97.

Marx, Karl and Friedrich Engels. 2007. "The German Ideology.” pp. 82-85 in Classical Sociological Theory. $2^{\text {nd }}$ ed., edited by Calhoun, Craig and Joseph Gerteis, James Moody, Steven Pfaff, and Indermohan Virk. Malden, MA: Blackwell Publishing.

Massey, Douglas S. and Mitchell L. Eggers. 1990. "The Ecology of Inequality: Minorities and the Concentration of Poverty, 1970-1980." American Journal of Sociology 95:1153-88. 
Massey, Douglas S. and Nancy A. Denton. 1985. "Spatial Assimilation as a Socioeconomic Outcome." American Sociological Review. 50(1): 94-106.

McKay, Dwanna L., Kirsten Vinyeta, and Kari Marie Norgaard. 2020. "Theorizing race and settler colonialism within U.S. sociology." Sociology Compass. 14(9): e12821.

Morris, Aldon. 2017. The Scholar Denied: W. E. B. Du Bois and the Birth of Modern Sociology. Univ of California Press.

Norgaard, Kari Mari. 2019. Salmon and Acorns Feed Our People: Colonialism, Nature \& Social Action. New Brunswick, NJ: Rutgers University Press.

Park, Robert E. and Ernest W. Burgess. 2019. The City. University of Chicago Press.

Pattillo, Mary. 1999. Black Picket Fences : Privilege and Peril Among the Black Middle Class. Chicago, IL: The University of Chicago.

Pattillo, Mary. 2007. Black on the Block: The Politics of Race And Class In The City. Chicago, IL: The University of Chicago.

Quillian, Lincoln. 2012. "Segregation and Poverty Concentration: The Role of Three Segregations." American Sociological Review 77(3) 354-79.

Ray, Ranita. 2018. The Making of a Teenage Service Class: Poverty and Mobility in an American City. Berkeley, CA: University of California Press.

Ray, Ranita and Korey Tillman. 2019. "Envisioning a Feminist Urban Ethnography: Structure, Culture, and New Directions in Poverty Studies." Sociology Compass 13(1):e12652.

Robinson, Cedric J. 2000. Black Marxism: The Making of the Black Radical Tradition. Chapel Hill, NC: University of North Carolina Press.

Rios, Victor. 2011. Punished: Policing the Lives of Black and Latino Boys. New York: New York University Press.

Rousseau, Jean-Jacques. 2007. "Of the Social Contract” pp. 44-54 in Classical Sociological Theory. $2^{\text {nd }}$ ed., edited by Calhoun, Craig and Joseph Gerteis, James Moody, Steven Pfaff, and Indermohan Virk. Malden, MA: Blackwell Publishing.

Rucks-Ahidiana, Zawadi. Forthcoming. "Racial Composition and Trajectories of Gentrification in the United States." Urban Studies.

Rugh, Jacob S. 2015. "Double Jeopardy: Why Latinos Were Hit Hardest by the US Foreclosure Crisis." Social Forces 93(3):1139-84.

Rugh, Jacob S., Len Albright, and Douglas S. Massey. 2015. "Race, Space, and Cumulative Disadvantage: A Case Study of the Subprime Lending Collapse." Social Problems 62(2):186-218.

Sampson, Robert J. 2012. Great American City: Chicago and the Enduring Neighborhood Effect. University of Chicago Press.

Seamster, Louise and Victor Ray. 2018. "Against Teleology in the Study of Race: Toward the Abolition of the Progress Paradigm." Sociological Theory 36(4):315-42.

Simmel, Georg. 1903. The Metropolis and Mental Life. Stimuli.

Small, Mario L., Robert A. Manduca, and William R. Johnston. 2018. "Ethnography, Neighborhood Effects, and the Rising Heterogeneity of Poor Neighborhoods across Cities." City \& Community 17(3):565-89.

Small, Mario Luis. 2008. "Four Reasons to Abandon the Idea of 'The Ghetto." City \& Community 7(4):389-98.

Small, Mario Luis. 2004. Villa Victoria: The Transformation of Social Capital in a Boston Barrio. Chicago: University of Chicago Press. 
Smith, Adam, and Edwin Cannan. 2003 (1776). The Wealth of Nations. New York, N.Y: Bantam Classic.

South, Scott J., Kyle Crowder, and Erick Chavez. 2005. "Migration and Spatial Assimilation Among U.S. Latinos: Classical Versus Segmented Trajectories." Demography 42(3):497-521.

Tach, L. M. (2014). Diversity, inequality, and microsegregation: Dynamics of inclusion and exclusion in a racially and economically diverse community. Cityscape, 16(3), 13-46.

Taylor, Keeanga-Yamahtta. 2019. Race for Profit: How Banks and the Real Estate Industry Undermined Black Homeownership. Chapel Hill: University of North Carolina Press.

Vargas, Robert. 2016. Wounded City: Violent Turf Wars in a Chicago Barrio. Oxford University Press.

Waren, Warren. 2013. “Houston's Emerging Exposure between African Americans and Whites: Evidence of Spatial Assimilation or Place Stratification?” Population, Space and Place 19(5):633-43.

Wells-Barnett, Ida Bell. 1892-1894. Southern Horrors: Lynch Law in All Its Phases. New York: New York Age Print.

Wirth, Louis. 1928. The Ghetto. Chicago, IL: University of Chicago Press.

Wright II, Earl. 2009. "Beyond W.E.B. Du Bois: A Note on Some of the Lesser Known Members of the Atlanta Sociological Laboratory." Sociological Spectrum 29(6):700-717.

Wright II, Earl. 2006. "W.E.B. Du Bois and the Atlanta University Studies on the Negro, Revisited." Journal of African American Studies 9(4):3-17.

Zorbaugh, Harvey Warren. 1983. The Gold Coast and the Slum: A Sociological Study of Chicago's Near North Side. University of Chicago Press.

Zuberi, Tukufu and Eduardo Bonilla-Silva. 2008. White Logic, White Methods: Racism and Methodology. Lanham, MD: Rowman \& Littlefield Publishers.

Zuberi, Tukufu. 2000. "Deracializing Social Statistics: Problems in the Quantification of Race." The Annals of the American Academy of Political and Social Science 568(1): 17285 . 